\title{
PEMANFAATAN LIMBAH BABI BIBIT SEBAGAI PENGHASIL BIOGAS
}

\author{
Efrad J. Takarenguang*, Jeanette E.M. Soputan, Vonny R. W. Rawung, \\ Jerry A.D. Kalele
}

Fakultas Peternakan Universitas Sam Ratulangi Manado, 95115

\begin{abstract}
ABSTRAK
Penelitian ini telah dilakukan dengan tujuan untuk mengkaji pemanfaatan limbah babi bibit sebagai biogas. Penelitian ini menggunakan analisis deskriptif. Variabel penelitian yang diamati meliputi volume gas, temperatur dan $\mathrm{pH}$. Hasil penelitian selama 31 hari menunjukkan bahwa total volume biogas yang diperoleh adalah $151842 \mathrm{ml}$. Dari data hasil penelitian diperoleh rata-rata temperatur di luar digester adalah $31^{\circ} \mathrm{C}$ sedangkan ratarata temperatur di dalam digester $29^{\circ} \mathrm{C}$. Nilai rata-rata $\mathrm{pH}$ hasil penelitian ini berkisar antara 6-7. Gas yang dihasilkan dalam penelitian ini selanjutnya dilakukan dua kali pengujian. Pengujian pertama, gas belum dapat dinyalakan, karena gas yang ada di dalam tong penampungan masih tercampur dengan berbagai jenis gas yang lainnya seperti $\mathrm{CO}_{2}$ dan Hydrogen Sulfida. Pengujian kedua, ternyata gas yang dihasilkan dapat menyala dengan konstan dan berwarna biru terang. Selanjutnya biogas diaplikasikan untuk memasak selama 34 menit. Dari hasil pengujian untuk mendidihkan air sebanyak 2 liter, membutuhkan waktu 16 menit dan gas yang dipakai sebanyak $64037 \mathrm{ml}$. Selanjutnya, untuk memasak dua butir telur membutuhkan waktu memasak selama 8 menit dan gas yang dipakai sebanyak $25747 \mathrm{ml}$, sedangkan untuk memasak dua bungkus mie instan membutuhkan waktu memasak selama 10 menit dan gas yang dipakai sebanyak 53474 ml. Kesimpulan dari penelitian ini adalah limbah ternak babi bibit dapat menghasilkan biogas yang dapat digunakan untuk memasak dan dapat menggantikan sumber energi
\end{abstract}

\footnotetext{
*Korespondensi (corresponding author):
}

Email: takarenguangefrad@yahoo.com konvensional seperti minyak tanah dan kayu bakar.

Kata Kunci : babi bibit, limbah, biogas

\section{ABSTRACT}

UTILIZATION OF BREEDING PIGS WASTE AS BIOGAS. This research has been conducted with the aim to examine the utilization of breeding pigs wastes as biogas. This research uses descriptive analysis which gas volume, temperature and acidity $(\mathrm{pH})$ as the observed variables. Result of 31 days research shown that obtained total biogas volume was $151842 \mathrm{ml}$. Average temperature of outer digester was $31^{\circ} \mathrm{C}$ while the average temperature of inner digester was $29^{\circ} \mathrm{C}$. The average of acidity $(\mathrm{pH})$ in this research ranged between 6-7. Then the resulting gas passed through twice testing. The first testing shown that the resulting gas has not been able to produce fire yet because biogas is mixed with another types of gases such as $\mathrm{CO}_{2}$ and hydrogen sulfide. The second testing shown that the resulting gas can be lit with a constant and bright blue fire. Then biogas was applied to cook for 34 minutes. The results shown that to boiling 2 liters of water takes 16 minutes and spends $64037 \mathrm{ml}$ of gas. Boiling 2 eggs takes 8 minutes and spends $25747 \mathrm{ml}$ of gas while boiling 2 packages of instant noodles takes 10 minutes and spends $53474 \mathrm{ml}$ of gas. As a conclusion of this research, waste of breeding pigs can produced biogas that can be use to cook and replace the conventional energy sources such as kerosene and firewood.

Keywords: breeding pigs, wastes and biogas 


\section{PENDAHULUAN}

Ternak babi merupakan salah satu komoditas peternakan yang cukup potensial untuk dikembangkan. Usaha peternakan babi dapat memberikan manfaat yang besar dilihat dari perannya sebagai penyedia protein hewani, namun manajemen yang kurang baik dari usaha peternakan babi terutama pada penanganan limbah dapat menyebabkan masalah gangguan ekosistem seperti pencemaran lingkungan (bau, gas beracun, dan hama penyakit) karena sebagian besar peternak mengabaikan penanganan limbah dari usahanya, bahkan ada yang membuang limbah usahanya ke sungai dan danau sehingga menuai protes dari warga sekitar.

Dalam mengembangkan usaha peternakan babi, harus diingat dampak negatifnya terhadap lingkungan hidup. Oleh karena itu, perlu dipikirkan perencanaan terpadu yang disamping mengoptimalkan produksi dan benefit, juga melibatkan pengendalian limbah dan pencegahan pencemaran lingkungan. Penerapan teknologi tepat guna dalam pemanfaatan limbah ternak babi bibit sebagai penghasil biogas memberikan multiplier effect. Selain menghasilkan biogas sebagai energi alternatif untuk memasak, juga memberikan dampak positif terhadap perkembangan usaha peternakan di Indonesia. Teknologi sederhana biogas juga diharapkan dapat menata kembali sistem pemeliharaan ternak babi, terutama sistem pemeliharaan ternak babi di pedesaan ke arah usaha budidaya ternak babi yang ramah lingkungan.

Menurut data statistik provinsi Sulawesi Utara tahun 2010, total populasi ternak babi di Indonesia berjumlah 6.183.550 ekor dan daerah Sulawesi Utara berada di urutan ke tujuh dengan jumlah populasi 332.942 ekor. Limbah yang dihasilkan oleh babi bibit dengan bobot badan $90-120 \mathrm{~kg}$ dapat mencapai $5,30 \mathrm{~kg}$ setiap hari. Berdasarkan data populasi tersebut tentunya limbah yang dihasilkan tidak sedikit dan memiliki potensi yang cukup besar untuk menghasilkan biogas jika dikelolah dengan baik. Selain itu rasio $\mathrm{C} / \mathrm{N}$ feses ternak babi 25. Kondisi ini sangat baik untuk perkembangan dan aktifitas mikroorganisme pembentuk metan jika digunakan sebagai bahan isian dalam proses pembuatan biogas.

Penelitian ini telah dilakukan untuk mengetahui produksi biogas yang dihasilkan melalui pemanfaatan limbah ternak babi bibit dan mengurangi resiko pencemaran lingkungan. 


\section{MATERI DAN METODE PENELITIAN}

Penelitian ini telah dilaksanakan pada bulan Agustus sampai September tahun 2015, bertempat di Balai Pengembangan Bibit dan Pakan Ternak Provinsi Sulawesi Utara. Analisis bahan pakan dilakukan di Laboratorium Ilmu dan Teknologi Pakan Fakultas Peternakan, Institut Pertanian Bogor. Bahan utama yang digunakan dalam penelitian ini adalah $136 \mathrm{~kg}$ limbah babi bibit dan air. Peralatan yang digunakan adalah digester tipe horisontal, meteran, thermometer batang air raksa $100^{\circ} \mathrm{C}$, kertas indikator $\mathrm{pH}$, kompor biogas, slang plastik untuk mengalirkan gas, bambu penyangga tong penampungan, sapu lidi, skep, ember plastik, gayung, dan timbangan kapasitas $10 \mathrm{~kg}$.

Model analisis data yang dipergunakan yaitu analisis deskriptif (Jogianto, 2008). Variabel yang diamati dalam penelitian ini adalah volume gas, temperatur, nilai $\mathrm{pH}$ dari limbah babi bibit setelah mengalami proses fermentasi di dalam digester.

\section{Pembuatan Alat Penghasil Biogas}

Cara pembuatan alat penghasil biogas di bagi dalam dua bagian mengacu pada Soputan (2012) :
1. Pembuatan Tabung Pencerna

- Tabung ini dibuat dari dua drum besar berukuran 200 liter, yang dirangkai dengan cara dilas. Kedua drum harus dibersihkan dan sebaiknya dicat. Caranya, drum pertama dibuka salah satu tutupnya (bagian yang ada bekas pemasukan minyak). Drum kedua dipotong separuh salah satu tutupnya (bagian yang ada bekas pemasukan minyak).

- Tepat di sisi tutup yang masi utuh pada kedua drum dibuat lubang dengan diameter $5 \mathrm{~cm}$.

- Pada posisi atas drum yang tutupnya terbuka dibuat lubang (berlawanan dengan posisi lubang berdiameter 5 $\mathrm{cm}$ ) berdiameter $1,5 \mathrm{~cm}$.

- Kedua drum dihubungkan dengan cara dilas. Kedua lubang yang telah dibuat (diameter $5 \mathrm{~cm}$ ) harus tepat di posisi dasar.

- Dilanjutkan dengan penyambungan pipa pemasukan isian sepanjang 60 $\mathrm{cm}$ yang di atasnya telah dilengkapi corong pada salah satu lubang dengan membentuk sudut $30^{\circ}$, lalu dilas. Untuk memperkuat kedudukanya, perlu ditopang dengan plat baja. Begitu juga dengan pipa pengeluaran buangan. 
2. Pembuatan tabung pengumpul gas

- Tabung pengumpul gas terbuat dari satu unit drum besar (200 liter) yang tidak bocor, dan satu unit drum yang lebih besar yang terbuat dari plateser.

- Drum besar (200 liter) dibuka salah satu tutupnya (bagian yang ada lubang bekas pemasukan minyak). Demikian pula dengan plateser dibuat terbuka salah satu tutupnya dan dicat.

- Pada tutup drum besar (200 liter) dibuat dua lubang berdiameter 1,5 $\mathrm{cm}$.

- Kemudian sambungkan pada kedua lubang tersebut dua pipa berdiameter $1,5 \mathrm{~cm}$ dengan cara dilas. Satu pipa untuk pemasukan gas dari tabung pencerna dan satu lagi yang telah dilengkapi dengan kran untuk pengeluaran gas.

\section{Proses Pengolahan Limbah Babi Bibit}

\section{Sebagai Penghasil Biogas}

- Pembuatan isian dengan mencampurkan kotoran ternak segar dengan air, perbandingan 1:1. Aduklah kotoran sampai merata sambil membuang benda-benda keras yang mungkin ikut tercampur.

- Masukkan isian yang telah siap kedalam tabung pencerna melalui pipa pemasukkan isian. Pada pengisian pertama, kran pengeluaran gas yang ada pada alat pencerna sebaiknya tidak disambungkan dulu ke pipa. Kran tersebut dibuka agar udara dalam alat pencerna terdesak keluar sehingga proses pemasukan lumpur kotoran lebih mudah. Pemasukan isian dihentikan setelah tabung pencerna penuh, yang ditandai dengan keluarnya buangan dari pipa buangan. Setelah tabung pencerna penuh, kran pengatur gas yang ada pada tabung pencerna ditutup dan biarkan digester memulai proses fermentasi.

- Buka kran pengeluaran gas dan hubungkan dengan pipa pemasukan gas tabung pengumpul dengan selang karet atau plastik yang telah disiapkan.

- Masukkan air kedalam drum besar tabung pengumpul gas sampai ketinggian sekitar $60 \mathrm{~cm}$.

- Masukkan pula drum kecil kedalam drum besar yang telah diisi air.

- Tutup kran pengeluaran gas tabung pengumpul gas.

- Setelah 3-4 minggu, biasanya gas pertama mulai terbentuk yang ditandai dengan terangkatnya drum kecil tabung pengumpul gas. Gas pertama ini perlu dibuang, dengan membuka kran pengeluaran gas tabung pengumpul, karena gas didominasi 
oleh gas $\mathrm{CO}_{2}$. Setelah gas pertama terbuang habis yang ditandai dengan turunnya permukaan drum kecil pengumpul gas ke posisi semula, kran pengeluaran gas ditutup kembali. Beberapa hari kemudian terjadi kenaikan tong penampungan gas selanjutnya setiap kenaikan per hari diukur dengan menggunakan rumus silinder.

\section{HASIL DAN PEMBAHASAN}

\section{Volume Biogas}

Hasil pengukuran volume biogas dari limbah babi bibit disajikan pada Gambar 1.

Pada Gambar 1 menunjukkan bahwa pada waktu retensi hari ke-1 sampai hari ke-4 tong penampungan gas belum terangkat itu menandakan belum ada gas yang dihasilkan. Hal ini karena yang aktif bekerja pada awal proses fermentasi yaitu bakteri hidrolitik yang memecah bahan organik menjadi gula dan asam amino yang akan menjadi bahan makanan untuk bakteri pada proses selanjutnya.

Pembentukan gas mulai terlihat pada waktu retensi hari ke-5 dan mengalami peningkatan yang signifikan hingga hari ke-14, selanjutnya pada hari ke-15 sampai hari ke-17 terjadi penurunan produksi gas. Penurunan produksi gas karena kran pengeluaran gas pada tong penampungan dibuka dengan tujuan untuk mengeluarkan berbagai jenis gas yang masih tercampur di dalam tong penampungan yang menyebabkan gas tidak menyala. Selanjutnya gas baru terbentuk pada waktu retensi hari ke-17

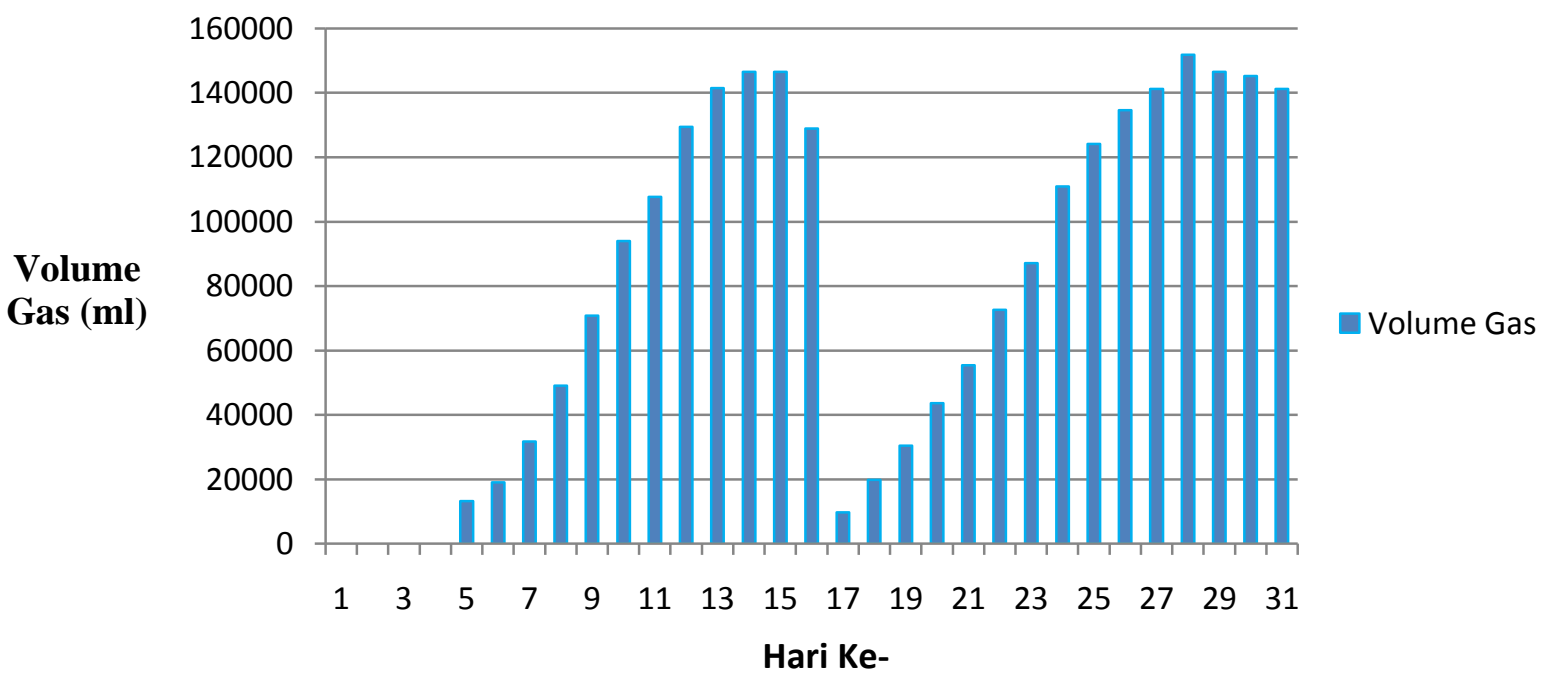

Gambar 1. Produksi biogas setiap hari 
dan mencapai puncaknya pada waktu retensi hari ke-28 dengan tinggi tong penampungan gas $57,5 \mathrm{~cm}$ dan volume gas $151842 \mathrm{ml}$ dan mengalami penurunan sampai pada waktu retensi hari ke-31.

Produksi biogas yang lambat disebabkan oleh pembentukan buih pada permukaan di dalam digester yang dapat menghambat produksi gas atau gas yang dihasilkan kurang (Sihombing et al., 1997). Setelah mancapai puncak produksi gas akan terjadi penurunan secara gradual. Hal ini di sebabkan oleh penurunan aktivitas bakteri anaerob, dengan adanya penurunan bahan organik yang telah mengalami degradasi menjadi komponen lain (Hadi, 1980 dalam Utomo dan Wahyuningsih, 2010).

\section{Temperatur}

Data hasil pengukuran temperatur digester disajikan dalam Gambar 2. Hasil pengamatan suhu udara dipagi hari pada pukul 08.00 berkisar antara $29^{\circ} \mathrm{C}-31^{\circ} \mathrm{C}$ dengan suhu rata-rata $30^{\circ} \mathrm{C}$ lebih rendah jika dibandingkan dengan suhu udara disore hari pada pukul 16.00 yaitu antara $27^{0} \mathrm{C}-32^{\circ} \mathrm{C}$ dengan suhu rata-rata $30^{\circ} \mathrm{C}$ tetapi cenderung mengalami penurunan pada hari ke-8 sampai pada hari ke 10 .

Gambar tersebut juga menunjukkan bahwa suhu dalam digester sore hari pada pukul $\quad 16.00$ yaitu antara $27^{\circ} \mathrm{C}-31^{\circ} \mathrm{C}$ dengan suhu rata-rata $29^{\circ} \mathrm{C}$ lebih tinggi jika dibandingkan dengan suhu pagi hari pada pukul 08.00 yang terjadi fluktuasi yaitu antara $27^{\circ} \mathrm{C}-29^{\circ} \mathrm{C}$ dengan suhu ratarata $28^{\circ} \mathrm{C}$. Hasil Penelitian menunjukkan

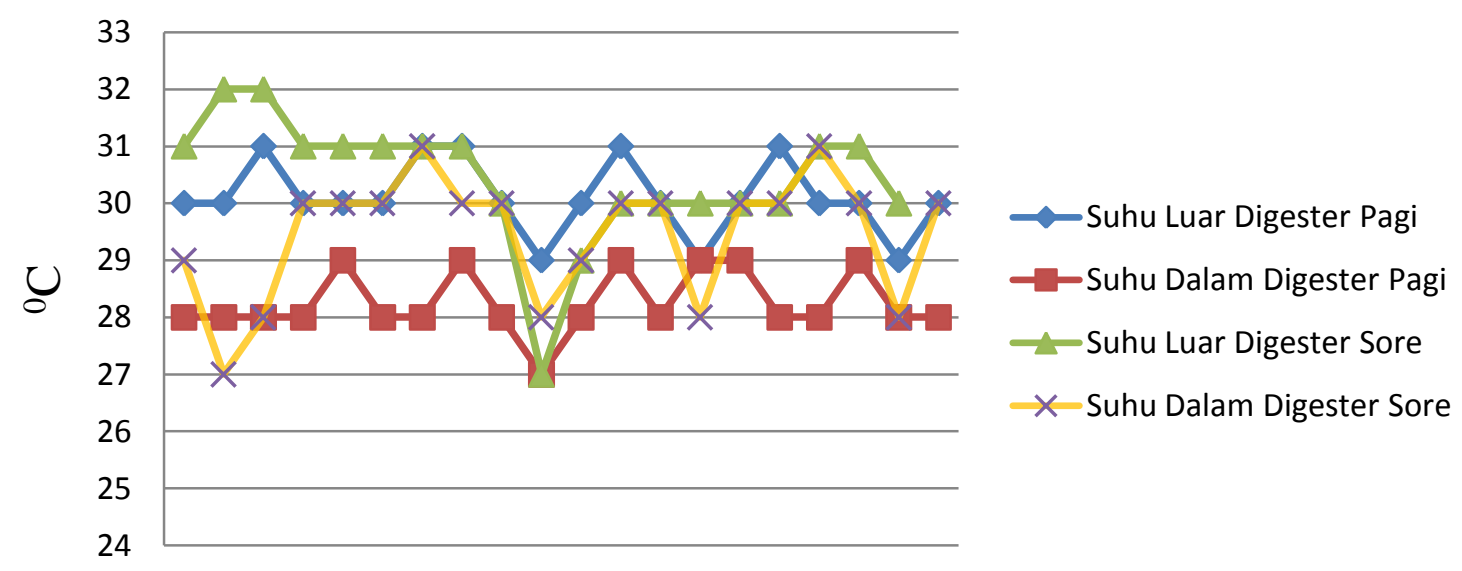

$122 \quad 3 \quad 4 \quad 5 \quad 6 \quad 7 \quad 8 \quad 91011121314151617181920$ Hari Ke-

Gambar 2. Suhu rata-rata harian 
bahwa rataan suhu dalam digester belum mencapai suhu optimum tetapi masih berada pada kisaran temperatur pencernaan anaerobik pada suhu $5-55^{\circ} \mathrm{C}$ (Hambali et al., 2007). Sedangkan suhu optimum untuk menghasilkan biogas adalah $35^{\circ} \mathrm{C}$ dimana pada suhu ini bakteri methanogenik bekerja optimal (Haryati, 2006).

Data yang diperoleh menunjukkan bahwa suhu digester sore hari pada hari ke-2 sampai hari ke-7, hari ke-10 sampai hari ke-12 dan hari ke-14 sampai hari ke17 cenderung mengalami peningkatan. Peningkatan suhu menunjukkan telah terjadi proses dekomposisi bahan organik, yang akan menghasilkan gas metan, karbon-dioksida, dan sejumlah gas lainnya. Suhu digester yang fluktuatif disebabkan karena digester diletakkan di tempat terbuka, sehingga suhu udara pada siang dan malam hari sangat mempengaruhi perubahan suhu di dalam digester, sehingga proses metanogenesis tidak optimal (Saseray et al., 2012). Selain itu, menurut Patel dan Madamwar (2002) perubahan suhu memiliki kompensasi yang besar terhadap kinerja bakteri anaerob. Produksi gas bio akan menurun akibat perubahan temperatur yang mendadak dalam digester dan perubahan temperatur yang tiba-tiba melebihi $3^{0} \mathrm{C}$ akan mempengaruhi proses produksi gas bio (Hadi, 1980 dalam Utomo dan Wahyuningsih, 2010).

\section{Derajat Keasamaan (pH)}

Hasil pengukuran $\mathrm{pH}$ dengan menggunakan kertas $\mathrm{pH}$ indikator berkisar antara 6,0 - 7,0. Jika dibandingkan dengan penelitian sebelumnya maka nilai $\mathrm{pH}$ yang diperoleh dapat dikatakan layak untuk proses fermentasi. Hasil pengamatan pada awal penelitian menunjukkan nilai $\mathrm{pH}$ berada dibawah $\mathrm{pH}$ optimum yaitu berkisar antara 4-5, hal ini yang menyebabkan pembentukan biogas di awal proses fermentasi berjalan lambat karena kondisi $\mathrm{pH}$ tersebut tidak memungkinkan untuk aktifitas bakteri metanogen. Nilai pH sangat mempengaruhi kualitas biogas yang dihasilkan sebagaimana dinyatakan Beni et al., dalam Mara dan Alit (2011), bahwa salah satu faktor yang mempengaruhi kualitas biogas yang dihasilkan adalah kadar $\mathrm{pH}$ bahan isian, kadar $\mathrm{pH}$ tersebut dipengaruhi kandungan air yang ada dalam bahan isian. Produk utama yang dihasilkan jika nilai $\mathrm{pH}$ yang terlalu tinggi adalah $\mathrm{CO}_{2}$. Nilai $\mathrm{pH}$ optimum yaitu antara 7-7,2 apabila $\mathrm{pH}$ turun akan menghambat pembentukan gas yang dapat mengakibatkan penurunan volume biogas. Saseray et al. (2012) menyatakan, bakteri-bakteri metanogenik sangat peka terhadap derajat keasaman 
sehingga pada kondisi $\mathrm{pH}$ yang tidak optimal dapat mempengaruhi produksi gas metan yang dihasilkan. Sejalan dengan pernyataan Sihombing (1997) jika pH di bawah optimum akan terjadi akumulasi amoniak yang dapat meracuni mikroorganisme apabila diatas $\mathrm{pH}$ optimal akan menghambat perkembangan dan aktifitas mikroorganisme pembentuk metan.

\section{Aplikasi Penggunaan Biogas}

Data hasil aplikasi penggunaan biogas disajikan dalam Tabel 1. Hasil pengamatan selama 31 hari, terjadi 2 kali tong penampungan mencapai maksimum dan 2 kali dilakukan pengujian gas. Pengujian pertama dilakukan dengan membuka penuh kran pengeluaran gas. Pengujian gas ini dilakukan pada saat volume tong penampung gas mencapai ketinggian 48,8 cm dengan volume gas $128868 \mathrm{ml}$. Hasil perhitungan menunjukkan 3 menit 40 detik waktu yang diperlukan tong penampungan untuk kembali ke posisi semula. Dari hasil pengujian gas yang dihasilkan belum dapat dinyalakan, hal ini diduga karena gas yang ada di dalam tong penampungan masih tercampur dengan berbagai macam gas seperti hidrogen sulfida, kandungan air, kandungan karbondioksida dan gas masih tercium seperti bau belerang (Simamora $e t$ al., 2006). Volume gas yang tinggi belum tentu mengandung konsentrasi gas metan yang tinggi sehingga perlu dilakukan pengujian terhadap konsentrasi gas metan yang dihasilkan (Saseray et al., 2012).

Pengujian yang kedua, aplikasi biogas untuk memasak dilakukan pada saat volume tong penampung gas mencapai maksimum yaitu pada ketinggian $57,5 \mathrm{~cm}$ dengan volume gas $151842 \mathrm{ml}$. Pengujian dilakukan menggunakan kompor khusus untuk biogas, ternyata gas yang dihasilkan dapat menyala dengan konstan dan berwarna biru terang. Hasil pengamatan untuk mendidihkan dua liter air membutuhkan waktu selama 16 menit dan gas sebanyak $64037 \mathrm{ml}$. Untuk dua butir telur membutuhkan waktu memasak

Tabel 1. Volume biogas dan waktu memasak

\begin{tabular}{lccc}
\hline Jenis Kegiatan & Banyak Bahan & Biogas $(\mathrm{ml})$ & Waktu (menit) \\
\hline Memasak Air & 2 liter air & 64037 & 16 \\
Telur Goreng & 2 butir & 25747 & 8 \\
Mie Kuah & 2 bungkus & 53474 & 10 \\
\hline Total & & 143260.1 & 34 \\
\hline
\end{tabular}


Tabel 2. Perbandingan Penggunaan Biogas, Kayu bakar dan Minyak tanah

\begin{tabular}{|c|c|c|c|c|}
\hline $\begin{array}{l}\text { Bahan } \\
\text { Bakar }\end{array}$ & $\begin{array}{l}\text { Volume } \\
\text { Air }\end{array}$ & $\begin{array}{l}\text { Waktu } \\
\text { (menit) }\end{array}$ & $\begin{array}{l}\text { Volume Bahan } \\
\text { Bakar }\end{array}$ & $\begin{array}{l}\text { Harga } \\
(\mathrm{Rp})\end{array}$ \\
\hline Biogas & 2 liter & 16 & $64037 \mathrm{ml}$ & - \\
\hline Minyak tanah & 2 liter & 15 & $280 \mathrm{ml}$ & 4200 \\
\hline Kayu bakar & 2 liter & 11 & $0,5 \mathrm{~kg}$ & 1800 \\
\hline
\end{tabular}

selama 8 menit dan gas yang dipakai sebanyak $25747 \mathrm{ml}$, sedangkan untuk memasak dua bungkus super mie membutuhkan waktu 10 menit dan gas yang dipakai sebanyak $53474 \mathrm{ml}$. Total lama nyala api yang diperoleh adalah 34 menit dan gas yang terpakai sebanyak $143260 \mathrm{ml}$. Gas yang masih terisisa dalam tong setelah digunakan sebanyak $8582 \mathrm{ml}$. Lama nyala api dan waktu yang diperlukan untuk memasak serta banyaknya gas yang terpakai tergantung dari besar kecilnya kran pengeluaran ketika dibuka pada saat penggunaan gas. Perbandingan penggunaan biogas, minyak tanah dan kayu bakar disajikan dalam Tabel 2. Pada Tabel 2 menunjukkan bahwa untuk memasak dua liter air, menggunakan biogas membutuhkan waktu yang paling lama yaitu 16 menit, memasak menggunakan minyak tanah membutuhkan waktu 15 menit 34 detik dan menggunakan kayu bakar lebih cepat waktu yang diperlukan yaitu 11 menit 13 detik.

Dari hasil penelitian ini, waktu yang diperoleh untuk memasak dengan menggunakan biogas lebih lama. Soputan (2012) menyatakan bahwa waktu yang lebih lama dengan menggunakan biogas, dapat disebabkan oleh lubang kompor biogas yang digunakan kecil. Kompor minyak tanah lebih cepat waktu memasaknya dari pada pengguanaan biogas, hal ini dapat disebabkan juga lubang kompor lebih besar. Penggunaan kayu bakar adalah yang tercepat dari pada menggunakan biogas dan minyak tanah. Hal ini dapat disebabakan sebaran panas lebih luas. Hasil aplikasi penggunaan biogas untuk memasak waktu yang diperlukan lebih lama dibandingkan dengan minyak tanah dan kayu bakar sama seperti yang dilakukan Kota (2009).

Efisiensi dari penggunaan biogas ini dapat dihitung berdasarkan hasil konversi dengan minyak tanah dan kayu bakar (Tabel 2). Gas yang dipakai untuk memasak 2 liter air adalah 64037 ml. Jika disetarakan dengan pemakaian dengan minyak tanah untuk memasak 2 liter air adalah $280 \mathrm{ml}$, harga minyak tanah untuk $280 \mathrm{ml}$ adalah Rp 4200. Pemakaian kayu bakar untuk memasak 2 liter air adalah 500 gram $(0,5 \mathrm{~kg})$, harga 500 gram kayu bakar adalah Rp 1800. 


\section{KESIMPULAN}

Limbah ternak babi bibit pada penelitian ini dapat menghasilkan biogas sebanyak $151842 \mathrm{ml}$ dengan waktu memasak selama 34 menit.

\section{DAFTAR PUSTAKA}

Hambali E., S. Mujdalipah, T. Halomoan, W. Pattiwiri dan R. Hendroko. 2007. Teknologi Bioenergi. Andromedia. Bogor.

Haryati, T. 2006. Limbah peternakan yang menjadi sumber energi alternatif. Balai Penelitian Ternak. WARTAZOA Volume 16 No. 3. http://kalteng.litbang.pertanian.go.id

Jogianto. 2008. Analisa dan Desain. Edisi VI. Penerbit Andi. Yogyakarta.

Kota, P.R. 2009. Pengembangan Teknologi Biogas Dengan Pemanfaatan Kotoran Ternak dan Jerami Padi Sebagai Alternatif Energi Pedesaan. Tesis. Pasca Sarjana IPB. Bogor

Mara, I. M dan Ida B. Alit. 2011. Analisa kualitas dan kuantitas biogas dari kotoran ternak. Jurnal Unram. Volume 1(2):
Patel, H. and D. Madamwar. 2002. Effects of temperatur and organic loading rates on biomethanation of acidic petrochemical wastewater using an anaerobic ufplow fixed-film reactor. J. Biortech. 82: 65-71.

Saseray D., S. Triatmojo, A. Pertiwiningrum. 2012. Pemanfaatan feses babi (Sus sp) sebagai sumber gas bio dengan penambahan ampas sagu (Metroxylon sp) pada taraf rasio $\mathrm{C} / \mathrm{N}$ yang berbeda. Buletin Peternakan Vol. 36 (3): 66-74

Sihombing, D. T. H. 1997. Ilmu Ternak Babi. Gadja Mada University Press. Yogyakarta

Simamora, S. Salundik, S. Wahyuni, Surajudin. 2006. Membuat Biogas Dari Kotoran Ternak. Cet. 5. Agromedia Pustaka. Jakarta.

Soputan, J. 2012. Pola Integrasi Ternak Babi Dengan Tanaman Ubi Jalar Yang Berwawasan Lingkungan di Minahasa. Disertasi. Program Pascasarjana, IPB. Bogor.

Utomo, S dan V. Wahyuningsih. 2010. Dosis campuran limbah sapi dengan limbah babi terhadap produksi gasbio. Jurnal Agrisains. Vol. 1: 7-14 